\title{
Thermacetogenium phaeum gen. nov., sp. nov., a strictly anaerobic, thermophilic, syntrophic acetate-oxidizing bacterium
}

\author{
Satoshi Hattori, ${ }^{1,2}$ Yoichi Kamagata, ${ }^{1}$ Satoshi Hanada ${ }^{1}$ \\ and Hirofumi Shoun ${ }^{2}$
}

\author{
Author for correspondence: Yoichi Kamagata. Tel: +81 29861 6591. Fax: +81 298616587. \\ e-mail:kamagata@nibh.go.jp
}

\footnotetext{
1 National Institute of Bioscience and Human Technology, Agency of Industrial Science and Technology, 1-1 Higashi, Tsukuba, Ibaraki 305-8566, Japan

2 Institute of Applied Biochemistry, University of Tsukuba, 1-1-1 Tennodai, Tsukuba, Ibaraki 305-8572, Japan
}

\begin{abstract}
A novel anaerobic, thermophilic, syntrophic acetate-oxidizing bacterium, strain $\mathrm{PB}^{\mathrm{T}}$, was isolated from a thermophilic $\left(55^{\circ} \mathrm{C}\right)$ anaerobic methanogenic reactor which had been treating kraft-pulp waste water. The bacterium oxidized acetate in co-culture with a thermophilic hydrogenotrophic methanogen. Strain PB $^{\top}$, a Gram-positive, spore-forming, rod-shaped bacterium grew optimally at $58{ }^{\circ} \mathrm{C}$ and $\mathrm{pH} 6.8$. The bacterium grew acetogenically on several alcohols, methoxylated aromatics, pyruvate, glycine, cysteine, formate and hydrogen/ $/ \mathrm{CO}_{2}$. Strain $\mathrm{PB}^{\mathrm{T}}$ also oxidized acetate with reduction of sulfate or thiosulfate as the electron acceptor. The bacterium contained MK-7 as the major quinone. The $\mathrm{G}+\mathrm{C}$ content of the DNA was $53.5 \mathrm{~mol} \%$. Comparative $16 \mathrm{~S}$ rDNA analysis indicated that strain $\mathrm{PB}^{\top}$ belongs to the Bacillus-Clostridium subphylum. However, it was distant from any known genera or microorganism. The closest known relative was Thermoterrabacterium ferrireducens with $87.4 \%$ similarity. The name Thermacetogenium phaeum gen. nov., sp. nov. is proposed. The type strain is strain PB' (= DSM 12270').
\end{abstract}

Keywords: Thermacetogenium phaeum gen. nov., sp. nov., thermophile, syntrophic acetate oxidation, acetogen, sulfate reduction

\section{INTRODUCTION}

Acetate is one of the most important intermediates for methanogenesis in anaerobic mineralization of organic materials. It has been estimated that approximately $70-80 \%$ of methane is derived from acetate in anoxic environments (Mountfort \& Asher, 1978; Mackie \& Bryant, 1981; Lovley \& Klug, 1982). Of the number of methanogens described, only the genera Methanosarcina and Methanosaeta are known to produce methane from acetate. Methanogenesis from acetate in these organisms is catalysed by an aceticlastic reaction in which the methyl group of acetate is reduced to methane (Ferry, 1992). In contrast to these organisms, some syntrophic proton-reducing organisms were found to oxidize acetate to form methane in association with hydrogenotrophic methanogens (Zinder \& Koch, 1984; Lee \& Zinder, 1988; Schnürer et al., 1994, 1996). Metabolically, this syntrophic association consists of two reactions that were originally proposed by

The GenBank/EMBL/DDBJ accession number for the $16 \mathrm{~S}$ rDNA sequence of strain $\mathrm{PB}^{\top}$ is $A B 020336$.
Barker (1936). In the first reaction, acetate is oxidized to form hydrogen and $\mathrm{CO}_{2}$, which are, in the second reaction, converted to methane. As with other anaerobic syntrophic fatty acid oxidations, the former reaction is thermodynamically unfavourable under standard conditions, unless it couples with the latter reaction (Stams, 1994; Schink, 1997). Thus, syntrophic acetate degradation is possible only when syntrophic and hydrogen-consuming micro-organisms cooperate. To date, two syntrophic acetate oxidizers in association with hydrogenotrophic methanogens are known. The first description was strain AOR, which was a thermophilic acetate oxidizer isolated from a methanogenic reactor in co-culture with Methanobacterium sp. (Zinder \& Koch, 1984). The isolate was later found to be a homoacetogen which forms acetate from hydrogen and $\mathrm{CO}_{2}$ in pure culture, whereas acetate oxidation, i.e. the reverse of acetogenesis, occurs in coculture with the methanogen (Lee \& Zinder, 1988). The second acetate syntroph described was Clostridium ultunense, which mesophilically oxidizes acetate in the presence of hydrogenotrophic methanogens (Schnürer et al., 1994, 1996). Although C. ultunense is phylo- 
genetically and chemotaxonomically well characterized, the phylogenetic position of the thermophilic strain AOR is not known. Moreover, the isolate has not been deposited in any culture collection and is no longer available. Considering the other findings that syntrophic oxidation may be involved in methanogenesis from acetate in thermophilic methanogenic reactors (Petersen \& Ahring, 1991; Uemura \& Harada, 1993), the phylogenetic position and the physiological traits of thermophilic acetate-oxidizing syntrophs are of great interest to elucidate their importance in the environment. Ten years ago, we found methanogenesis from acetate in a thermophilic methanogenic enrichment in which neither Methanosarcina- nor Methanosaeta-like cells were observed (Kamagata \& Mikami, 1989). In this report, we describe the isolation and characterization of a new thermophilic, syntrophic acetate-oxidizing bacterium, strain $\mathrm{PB}^{\mathrm{T}}$, from the enrichment and propose a new name for the isolate.

\section{METHODS}

Source of organisms. The syntrophic acetate-oxidizing bacterium, strain $\mathrm{PB}^{\mathrm{T}}$, and a thermophilic hydrogenand formate-utilizing methanogen, Methanothermobacter thermoautotrophicus strain TM (previously Methanobacterium thermoautotrophicum) were isolated from a thermophilic $\left(60^{\circ} \mathrm{C}\right)$ anaerobic methanogenic reactor that treated waste water from a kraft-pulp production plant in Japan. $M$. thermoautotrophicus strain $\Delta H$ (= DSM 1053) was obtained from the DSMZ (Braunschweig, Germany).

Media and cultivation. The composition of the basal medium used for all experiments was based on DSM 334 medium (DSMZ, 1983). The basal medium contained (per litre): $1.0 \mathrm{~g} \mathrm{NH}_{4} \mathrm{Cl}, 0 \cdot 3 \mathrm{~g} \mathrm{KH}_{2} \mathrm{PO}_{4}, 0.6 \mathrm{~g} \mathrm{NaCl}, 0 \cdot 1 \mathrm{~g} \mathrm{MgCl}_{2} .2 \mathrm{H}_{2} \mathrm{O}$, $0.08 \mathrm{~g} \mathrm{CaCl}_{2} .2 \mathrm{H}_{2} \mathrm{O}, 3.5 \mathrm{~g} \mathrm{KHCO}_{3}, 1 \mathrm{mg}$ sodium resazurin, $10 \mathrm{ml}$ vitamin solution and $5 \mathrm{ml}$ trace element solution. The vitamin solution was replaced with that of DSM 141 medium (DSMZ, 1983). The composition was as follows (per litre): $2.0 \mathrm{mg}$ biotin, $2.0 \mathrm{mg}$ folic acid, $10.0 \mathrm{mg}$ pyridoxine hydrochloride, $5.0 \mathrm{mg}$ thiamin hydrochloride, $5.0 \mathrm{mg}$ riboflavin, $5.0 \mathrm{mg}$ nicotinic acid, $5.0 \mathrm{mg}$ DL-calcium pantothenate, $0.1 \mathrm{mg}$ vitamin $\mathrm{B}_{12}, 5.0 \mathrm{mg} p$-aminobenzoate and $5.0 \mathrm{mg}$ lipoic acid. The trace element solution was based on DSM 318 medium (DSMZ, 1983) and contained (per litre): $12.8 \mathrm{~g}$ nitrilotriacetic acid, $1.35 \mathrm{~g} \quad \mathrm{FeCl}_{3} .6 \mathrm{H}_{2} \mathrm{O}, 0.1 \mathrm{~g}$ $\mathrm{MnCl}_{2} .4 \mathrm{H}_{2} \mathrm{O}, 0.024 \mathrm{~g} \mathrm{CoCl} \mathrm{Co}_{2} \cdot 6 \mathrm{H}_{2} \mathrm{O}, 0 \cdot 1 \mathrm{~g} \mathrm{CaCl} \mathrm{Ca}_{2} \cdot 2 \mathrm{H}_{2} \mathrm{O}$, $0.1 \mathrm{~g} \mathrm{ZnCl}{ }_{2}, 0.025 \mathrm{~g} \mathrm{CuCl}_{2} .2 \mathrm{H}_{2} \mathrm{O}, 0.01 \mathrm{~g} \mathrm{H}_{3} \mathrm{BO}_{3}, 0.024 \mathrm{~g}$ $\mathrm{Na}_{2} \mathrm{MoO}_{4} \cdot 4 \mathrm{H}_{2} \mathrm{O}, 1 \cdot 0 \mathrm{~g} \mathrm{NaCl}, 0 \cdot 12 \mathrm{~g} \mathrm{NiCl}{ }_{2} .6 \mathrm{H}_{2} \mathrm{O}, 4.0 \mathrm{mg}$ $\mathrm{Na}_{2} \mathrm{SeO}_{3} .5 \mathrm{H}_{2} \mathrm{O}, 4 \cdot 0 \mathrm{mg} \mathrm{Na} \mathrm{WO}_{4} \cdot 2 \mathrm{H}_{2} \mathrm{O}$. The trace element solution was adjusted to $\mathrm{pH} 6.5$ with $1 \mathrm{M} \mathrm{KOH}$. For growth of the syntrophic acetate-oxidizing co-culture, the medium contained $80 \mathrm{mM}$ sodium acetate. For the isolation and maintenance of strain $\mathrm{PB}^{\mathrm{T}}, 80 \mathrm{mM}$ sodium pyruvate was used as the substrate. The medium was anaerobically dispensed into serum vials or bottles under $\mathrm{N}_{2} / \mathrm{CO}_{2}(4: 1$, $\mathrm{v} / \mathrm{v}$ ) atmosphere. The vials or bottles were sealed with butyl rubber stoppers fitted with caps. The medium was autoclaved for $20 \mathrm{~min}$ at $121^{\circ} \mathrm{C}$. The $\mathrm{pH}$ of the autoclaved medium was approximately $6 \cdot 9-7 \cdot 1$. Prior to inoculation, the medium was reduced with sterile stock solutions of $\mathrm{Na}_{2} \mathrm{~S}$ and cysteine $/ \mathrm{HCl}$ (final concentration $0.3 \mathrm{~g}^{-1}$ each). Unless otherwise noted, cultures were incubated at $55^{\circ} \mathrm{C}$ in the dark without shaking.

Determination of growth. To determine the growth, a $25 \mathrm{ml}$
Hungate tube containing $10 \mathrm{ml}$ medium was used. Growth was determined by measuring $\mathrm{OD}_{660}$ with a Hitachi spectrophotometer model 100-10. Unless otherwise noted, the growth experiments were performed at least in duplicate.

Temperature, $\mathrm{pH}$ and $\mathrm{NaCl}$ ranges for growth. Medium containing $20 \mathrm{mM}$ sodium pyruvate was used, and a late-log culture of strain $\mathrm{PB}^{\mathrm{T}}$ was inoculated into the fresh basal medium. For determination of the temperature ranges for growth, cultures were incubated at $30-70{ }^{\circ} \mathrm{C}$. For the $\mathrm{pH}$ experiment, the $\mathrm{pH}$ of the medium was adjusted with sterile stock solutions of $10 \% \mathrm{~K}_{2} \mathrm{CO}_{3}$ or $1 \mathrm{M} \mathrm{HCl}$. The $\mathrm{pH}$ value was calibrated at $25^{\circ} \mathrm{C}$. The range of $\mathrm{pH}$ tested was 5.4-9.1.To determine the effect of salt concentrations on growth, sodium chloride was added to the medium before autoclaving to give final concentrations of 0.05 to $5 \%$.

Determination of acetate-oxidation rate. The acetate-oxidation rate $\left[\mathrm{mmol}\right.$ acetate consumed $\left.\mathrm{h}^{-1}(\mathrm{~g} \text { dry cell } \mathrm{wt})^{-1}\right]$ was determined by using washed-cell suspension. Strain $\mathrm{PB}^{\mathrm{T}}$ was co-cultured with Methanothermobacter thermoautotrophicus strain TM on medium containing $80 \mathrm{mM}$ acetate $(500 \mathrm{ml})$ for a month. The cells were harvested anaerobically, suspended in the acetate medium $(20 \mathrm{ml})$ and incubated at $55^{\circ} \mathrm{C}$. Methane and acetate were determined at appropriate intervals.

Utilization of substrates and electron acceptors. Several compounds including organic acids, alcohols, methoxylated aromatics, sugars, amino acids and hydrogen were used for the substrate-utilization tests. Substrates were added from filter-sterilized or autoclaved stock solutions ( $\mathrm{pH}$ 7.0) to give the desired concentrations. When hydrogen was used as the substrate, the head space $(15 \mathrm{ml})$ of the tube was replaced with hydrogen $/ \mathrm{CO}_{2}(4: 1, \mathrm{v} / \mathrm{v}, 151 \mathrm{kPa})$. For determining electron acceptors, $40 \mathrm{mM}$ sodium acetate was used as the electron donor, and the following organic or inorganic compounds were tested as electron acceptors $(\mathrm{mM})$ : sulfate (20), sulfite $(2 \cdot 5)$, nitrate $(20)$, nitrite $(2 \cdot 5)$, thiosulfate $(20)$, amorphous $\mathrm{Fe}(\mathrm{III})$ (5) and fumarate (10). Two negative controls were incubated simultaneously: (1) medium containing strain $\mathrm{PB}^{\mathrm{T}}$ and acetate but without an electron acceptor and (2) the medium containing acetate and electron acceptor but without cells.

Microscopy. Cultures were routinely examined with an Olympus model AX-80 microscope equipped with phasecontrast and epifluorescence apparatus. For transmission electron microscopy, cells were centrifuged and fixed with $5 \%(\mathrm{v} / \mathrm{v})$ glutaraldehyde and $1 \%(\mathrm{v} / \mathrm{v})$ osmium tetroxide. The samples were embedded in Spurr resin and the ultrathin sections of the samples were prepared with a ReinchertNissei ultramicrotome. The samples were stained with $1 \%$ uranyl acetate and $0.3 \%$ lead citrate. After treatment of vapor deposition with carbon, the samples were observed using a Hitachi model $\mathrm{H}-7000$ electron microscope operating at $75 \mathrm{kV}$.

Analytical methods. Methane was analysed by a Shimadzu model GC-8AIT gas chromatograph equipped with a molecular sieve 5A 60/80 mesh column and a thermal conductivity detector. Argon was used as the carrier gas at a flow rate of $27 \mathrm{ml} \mathrm{min}$. The column and the detector temperatures were kept at $60^{\circ} \mathrm{C}$ and $110^{\circ} \mathrm{C}$, respectively. Acetate and fermentation products were determined by using a Shimadzu model LC-6A HPLC equipped with a Shimadzu SCR-101H column and a model SPD-6A UV detector. The column was operated at $40{ }^{\circ} \mathrm{C}$, and $17 \mathrm{mM}$ $\mathrm{HClO}_{4}$ was used as the eluent at a flow rate of $1 \mathrm{ml} \mathrm{min}{ }^{-1}$. Sulfate, sulfite, nitrate, nitrite and thiosulfate were determined by using a Shimadzu model LC-6A HPLC 
equipped with a Shimadzu IC-A3 ion-exchange column and a model CDD-6A electronic conductivity detector. Operating conditions were as follows: column temperature, $40{ }^{\circ} \mathrm{C}$; eluent, $8.0 \mathrm{mM}$ p-hydroxybenzoic acid and $3.2 \mathrm{mM}$

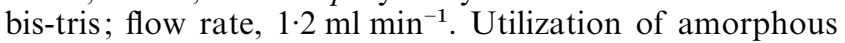
$\mathrm{Fe}(\mathrm{III})$ was assessed by measuring changes in the visible colour of the medium (Slobodkin et al., 1997a).

DNA extraction and purification. Genomic DNA was extracted and purified according to the method of Hiraishi (1992). For determination of DNA base composition, the crude DNA was further purified with an equal volume of phenol/chloroform/isoamylalcohol (25:24:1, by vol).

DNA base composition. The $\mathrm{G}+\mathrm{C}$ content of strain $\mathrm{PB}^{\mathrm{T}}$ was determined by enzymic digestion of genomic DNA and HPLC separation using a Yamasa GC kit as described by Kamagata \& Mikami (1991). The purified DNA sample was separated by using a Shimadzu model LC-6A HPLC equipped with a Shimadzu CLC-ODS reverse-phase column and a model SPD-6A UV detector at $270 \mathrm{~nm}$. The column was operated at $40^{\circ} \mathrm{C}$, and $10 \mathrm{mM}$ potassium phosphate buffer ( $\mathrm{pH} 3.5)$ containing $5 \%$ methanol was used as the

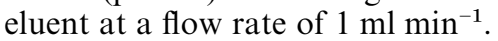

Amplification and purification of 16S rDNA. Crude DNA was used as template for PCR amplification of $16 \mathrm{~S} \mathrm{rDNA}$. PCR was performed by using an AmpliTaq Gold reagent kit (Perkin Elmer) according to the manufacturer's protocol. The PCR primers used for amplification were the forward primer 8F (5'-AGAGTTTGATCCTGGCTCAG-3', Escherichia coli positions 8-27) and the reverse primer 1491R (5'-GGTTACCTTGTTACGACTT-3', E. coli positions 1509-1491) (Weisburg et al., 1991). PCR conditions were as follows: pre-heating at $95^{\circ} \mathrm{C}$ for $9 \mathrm{~min}, 35$ cycles of denaturing at $95{ }^{\circ} \mathrm{C}$ for $1 \mathrm{~min}$, annealing at $50{ }^{\circ} \mathrm{C}$ for $1 \mathrm{~min}$ and extension at $72{ }^{\circ} \mathrm{C}$ for $2 \mathrm{~min}$.

16S rDNA sequence determination and phylogenetic analysis. Purified PCR products of $16 \mathrm{~S}$ rDNA were sequenced directly with a PRISM dRhodamine Terminator Cycle Sequencing Ready Reaction Kit (Applied Biosystems) according to the manufacturer's protocol. Six primers were used for sequencing according to the method of Hiraishi (1992). Both obtained and reference 16S rDNA sequences were aligned with the CLUSTAL W program, version 1.5 (Thompson et al., 1994). The phylogenetic tree was constructed by the neighbour-joining method (Saito \& Nei, 1987) with the MEGA program. Bootstrap values were obtained for 100 replicates to estimate the confidence of tree topologies.

Quinone analysis. Quinone was determined according to the method of Tamaoka et al. (1983). Approximately $2 \mathrm{~g}$ (wet weight) of the late-exponential-phase culture of strain $\mathrm{PB}^{\mathrm{T}}$ grown on pyruvate was used for the analysis.

Nucleotide sequence accession numbers. The $16 \mathrm{~S}$ rDNA sequence of strain $\mathrm{PB}^{\mathrm{T}}$ has been deposited in the DDBJ/ GenBank/EMBL database under the accession number AB020336. The accession numbers of the reference sequences used in the phylogenetic analysis are as follows: Thermoterrabacterium ferrireducens DSM 11225 , U76364; Moorella glycerini DSM 11254 ${ }^{\mathrm{T}}$, U82327; Moorella thermoacetica ATCC 39073 ${ }^{\mathrm{T}}$, M59121; Moorella thermoautotrophica DSM 1974 ${ }^{\mathrm{T}}$, L09168; Thermoanaerobacter ethanolicus DSM 2355 ${ }^{\mathrm{T}}$, L09164; Thermoanaerobacterium thermosulfurigenes DSM 2229 ${ }^{\mathrm{T}}$, L09171; Syntrophomonas wolfei DSM 2245 ${ }^{\mathrm{T}}$, AF022248; Syntrophospora bryantii DSM 3014 ${ }^{\mathrm{T}}$, M26491; Thermosyntropha lipolytica DSM
$11003^{\mathrm{T}}$, X99980; Desulfotomaculum australicum DSM 11792, M96665; Desulfotomaculum thermoacetoxidans DSM $5813^{\mathrm{T}}$, Y11573; Desulfotomaculum thermobenzoicum DSM 6193 ${ }^{\mathrm{T}}$, Y11574; Desulfotomaculum nigrificans DSM 574 ${ }^{\mathrm{T}}$, X62176; Desulfotomaculum ruminis DSM 2154" , Y11572; Bacillus subtilis NCDO 1769, X60646; Clostridium ultunense DSM 10521 ${ }^{\mathrm{T}}$, Z69293; Clostridium butyricum DSM 552 ${ }^{\mathrm{T}}$, M59085; Arthrobacter globiformis DSM 20124 ${ }^{\mathrm{T}}$, X80736.

\section{RESULTS}

\section{Enrichment and isolation}

Strain $\mathrm{PB}^{\mathrm{T}}$ was originally derived from an enrichment culture which converted acetate to methane. For the primary enrichment of a syntrophic acetate-oxidizing co-culture, a sample taken from a thermophilic anaerobic reactor was serially diluted and inoculated into the basal medium containing $80 \mathrm{mM}$ sodium acetate. After 2 months incubation at $55^{\circ} \mathrm{C}$, the cultures receiving $10^{-1}$ to $10^{-6}$ dilutions completely degraded acetate and produced nearly equimolar amounts of methane. Under microscopic observation, the cultures receiving $10^{-1}$ to $10^{-4}$ dilutions contained several kinds of microbes such as Methanobacterium- and Methanosaeta-like methanogens. However, neither Methanosarcina nor Methanosaeta-like cells were observed in the cultures that received the $10^{-5}$ to $10^{-6}$ dilutions. The highest-dilution culture was again serially diluted into fresh acetate medium. After several transfers, the culture was found to be composed of two morphologically distinct rod-shaped bacteria. One organism had a terminal endospore and showed nonautofluorescence. The other, showing autofluorescence indicative of $\mathrm{F}_{420}$, was morphologically similar to Methanobacterium cells. Neither Methanosarcina nor Methanosaeta types of methanogen were found. These observations suggested that syntrophic acetate oxidation, as has been previously described by Zinder \& Koch (1984) and Schnürer et al. (1994) occurred in the culture. However, the culture was not still a defined coculture, since other types of heterotroph appeared vigorously when the culture was incubated with yeast extract or other carbon sources such as glucose and tryptone. To eliminate those contaminants, we tried to repeat serial dilutions, roll-tube culture or antibioticcontaining culture. However, all attempts were unsuccessful. Therefore, we tried to isolate each member separately from the culture. For isolation of the syntrophic acetate-oxidizing bacterium, several compounds such as ethylene glycol were tested according to the method previously described (Lee \& Zinder, 1988; Schnürer et al., 1996). Of the substrates tested, $80 \mathrm{mM}$ sodium pyruvate allowed a spore-forming bacterium to grow after $7 \mathrm{~d}$ incubation at $55^{\circ} \mathrm{C}$. The microbe resembled the bacterium which had predominated as well as Methanobacterium-like cells in the enrichment. We therefore focused on this bacterium and inoculated the cells into a $2 \%$ agar (Agar Noble, Difco) medium containing $80 \mathrm{mM}$ pyruvate as the sole carbon and energy source. After 2 months incubation, the colonies which grew up to $2 \mathrm{~mm}$ in 


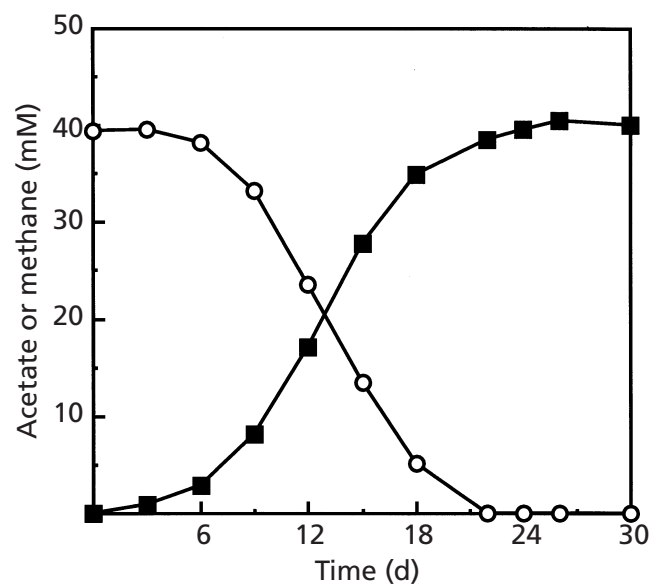

Fig. 1. Syntrophic degradation of acetate to methane by a reconstituted co-culture of strain $\mathrm{PB}^{\top}$ and $M$. thermoautotrophicus strain TM. $\bigcirc$, acetate; $\mathbf{\square}$, methane.

diameter were picked with a sterile Pasteur pipette and subcultured in liquid medium containing $80 \mathrm{mM}$ pyruvate and $20 \mathrm{mM}$ BES. Purity of the strain, designated $\mathrm{PB}^{\mathrm{T}}$, was checked by inoculating it into the medium containing $0 \cdot 1 \%$ yeast extract and $1 \%$ Bacto Tryptone (Difco), and by microscopy. The thermophilic hydrogen- and formate-utilizing methanogen, $M$. thermoautotrophicus strain TM was also isolated from the primary enrichment culture by using the same procedure, except that pyruvate was replaced with hydrogen $/ \mathrm{CO}_{2}(4: 1, \mathrm{v} / \mathrm{v}, 151 \mathrm{kPa})$ and $\mathrm{BES}$ was omitted.

\section{Reconstruction of syntrophic acetate-oxidizing co-culture}

To prove strain $\mathrm{PB}^{\mathrm{T}}$ to be a syntrophic acetateoxidizing bacterium, strains $\mathrm{PB}^{\mathrm{T}}$ and $\mathrm{TM}$ were coinoculated into basal medium containing $80 \mathrm{mM}$ sodium acetate as the sole carbon and energy source, and incubated at $55^{\circ} \mathrm{C}$. As the control experiments, strains $\mathrm{PB}^{\mathrm{T}}$ and $\mathrm{TM}$ were separately inoculated under the same conditions. Growth was observed only in the mixed culture after $40 \mathrm{~d}$ incubation. Acetate was converted to methane. The co-culture was able to retain methanogenic activity from acetate after further transfer into the fresh medium. Fig. 1 shows that the co-culture completely degraded $40 \mathrm{mM}$ acetate and stoichiometrically produced methane within $24 \mathrm{~d}$. The acetate-oxidation rate using washed-cell suspension was calculated to be $1.29 \mathrm{mmol}$ acetate consumed $\mathrm{h}^{-1}$ $(\mathrm{g} \text { dry cell wt })^{-1}$. Strain $\mathrm{PB}^{\mathrm{T}}$ could also be co-cultured with a hydrogen-utilizing methanogen, $M$. thermoautotrophicus strain $\Delta \mathrm{H}$.

\section{Colony and cell morphology}

Colonies of strain $\mathrm{PB}^{\mathrm{T}}$ were disc shaped, 1.0-3.0 $\mathrm{mm}$ in diameter, smooth and brownish. Figs 2 and 3 show the morphology and ultrathin sections of the syntrophic
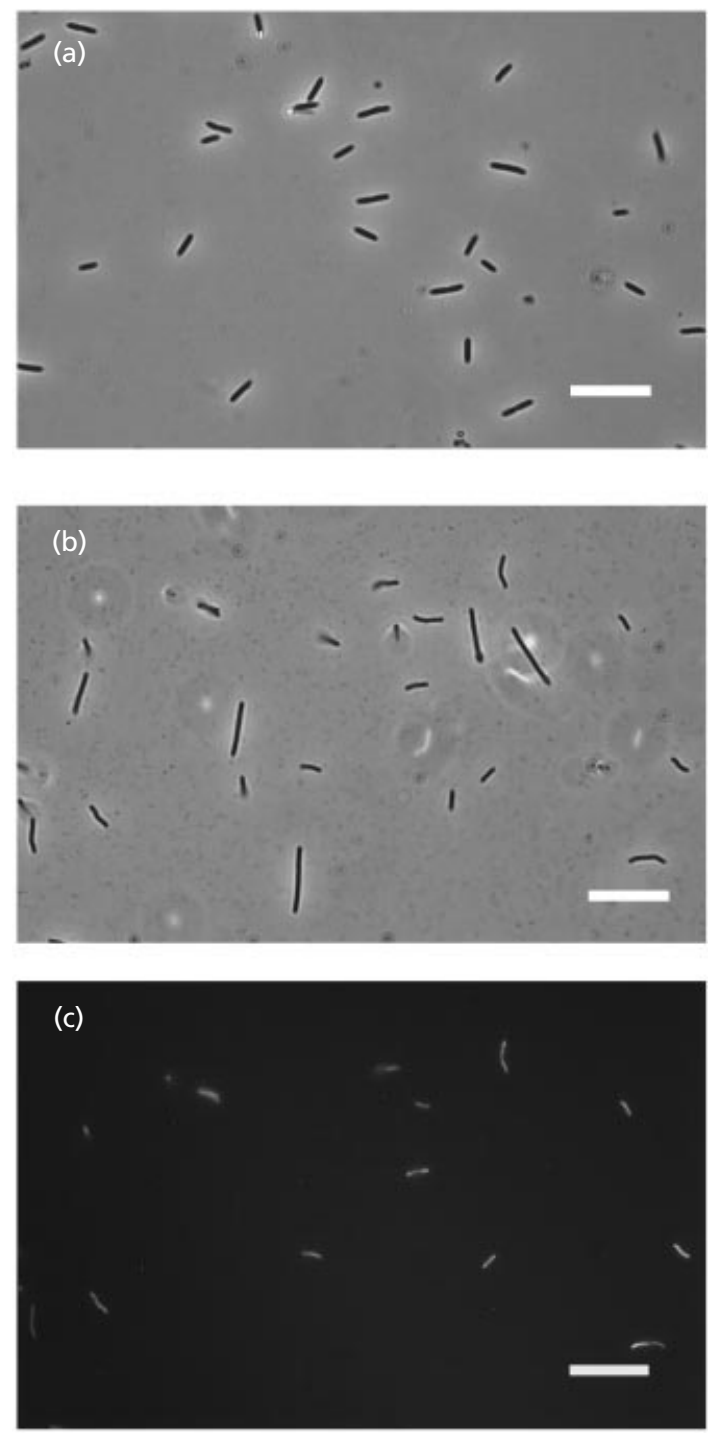

Fig. 2. (a) Phase-contrast micrograph of strain $P B^{\top}$ in pure culture grown on methanol; (b) co-culture of strain $\mathrm{PB}^{\top}$ with $M$. thermoautotrophicus strain TM grown on acetate; (c) epifluorescence micrograph of the same field as (b). Bars, $10 \mu \mathrm{m}$.

co-culture and the pure culture of strain $\mathrm{PB}^{\mathrm{T}}$. Gramstaining was negative. However, transmission electron microscopy indicated a Gram-positive type of cell wall (Fig. 3). Cells were straight or slightly curved rods with rounded ends, $0.4-0.7 \mu \mathrm{m}$ wide and $2 \cdot 0-12.6 \mu \mathrm{m}$ long. The cells occurred singly, in pairs or in chains depending on the growth phase and growth conditions, i.e. under syntrophic conditions, strain $\mathrm{PB}^{\mathrm{T}}$ elongated the cell length at late-exponential phase and occurred singly. In pure culture, the cells often occurred in pairs or in chains at the exponential phase. Terminal endospores were much more frequently observed in the syntrophic co-culture than in the pure culture (Fig. 3). 

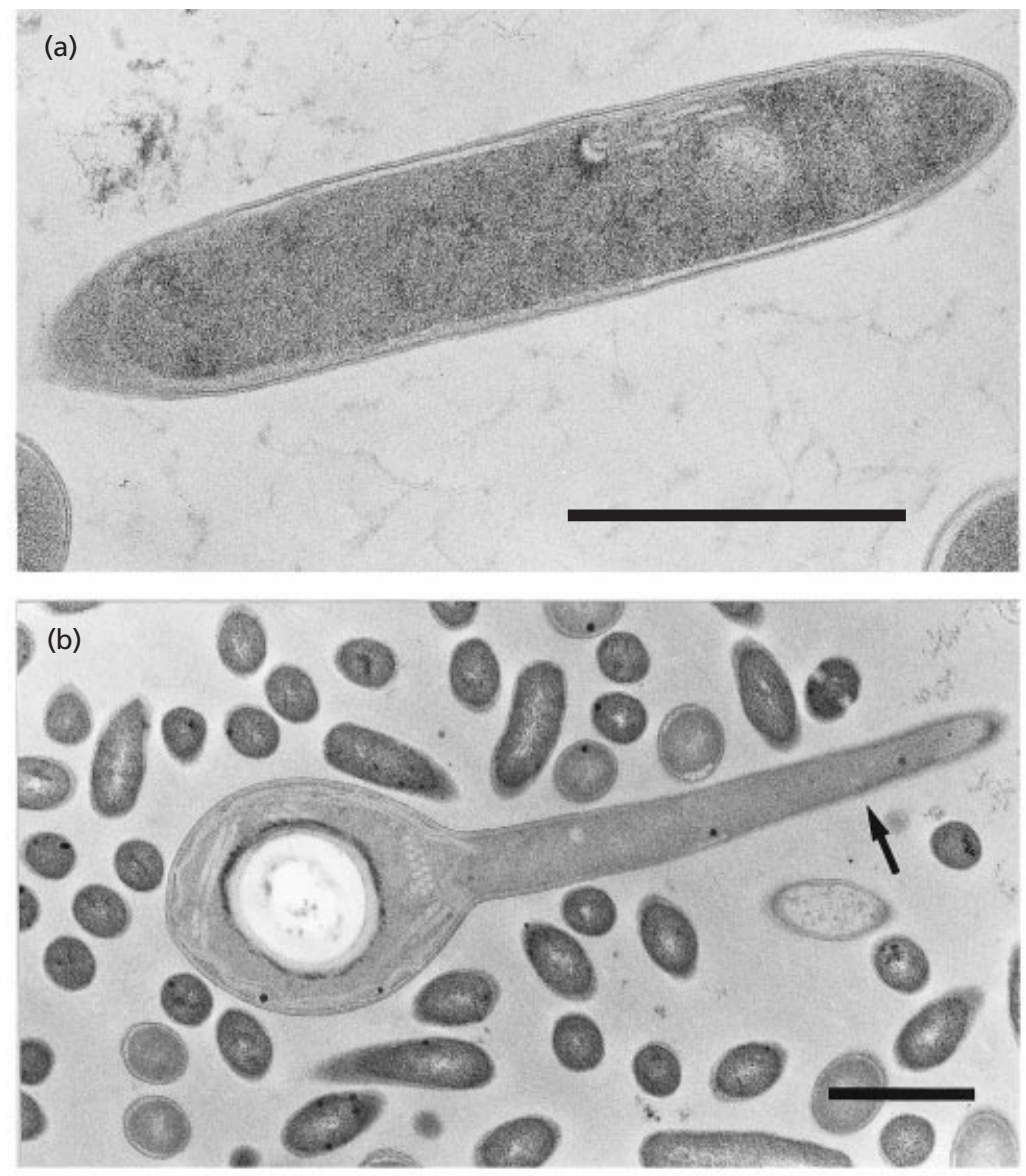

Fig. 3. Transmission electron micrographs of pure culture (a) and syntrophic co-culture showing a terminal endospore (b). The arrow in (b) indicates the strain $\mathrm{PB}^{\top}$ cell. Bars, $1 \mu \mathrm{m}$.

\section{Growth properties}

The temperature range for growth of strain $\mathrm{PB}^{\mathrm{T}}$ was $40-65{ }^{\circ} \mathrm{C}$, with an optimum temperature around $58^{\circ} \mathrm{C}$ (Fig. 4a). No growth was observed within 2 months at $35^{\circ} \mathrm{C}$ and $70{ }^{\circ} \mathrm{C}$. The $\mathrm{pH}$ range for growth was 5.9-8.4 and optimal growth was at pH 6.8 (Fig. 4b). Growth was not observed at $\mathrm{pH} 5.4$ and $\mathrm{pH} 8.8$. The doubling time under the optimum conditions was calculated to be $22.8 \mathrm{~h}$. Strain $\mathrm{PB}^{\mathrm{T}}$ was able to grow at $\mathrm{NaCl}$ concentrations ranging from 0.05 to $4.5 \%(\mathrm{w} / \mathrm{v})$.

\section{Substrate utilization}

The following substrates were utilized for growth in pure culture (unless otherwise noted, substrates were added at a final concentration of $20 \mathrm{mM}$ ): methanol, ethanol, n-propanol, n-butanol, 2,3-butanediol, ethanolamine, pyruvate, 3,4,5-trimethoxybenzoate $(10 \mathrm{mM})$, syringate $(10 \mathrm{mM})$, vanillate $(10 \mathrm{mM})$, glycine, cysteine, formate $(40 \mathrm{mM})$ and hydrogen $/ \mathrm{CO}_{2}$ $(4: 1, \mathrm{v} / \mathrm{v}, 151 \mathrm{kPa})$. Acetate was the sole or major fermentation product from these substrates. In coculture with hydrogenotrophic methanogens, the bacterium syntrophically oxidized acetate $(40 \mathrm{mM})$ to form methane. No growth was observed on 1,2propanediol, ethylene glycol, glycerol, citrate, fumarate, malate, lactate, sarcosine, betaine, methylamine, dimethylamine, trimethylamine, glucose, fructose, galactose, maltose, sucrose, lactose and yeast extract $(0 \cdot 1 \%)$.

\section{Electron acceptors}

In the presence of sulfate, strain $\mathrm{PB}^{\mathrm{T}}$ consumed $12 \mathrm{mM}$ acetate (initial concentration, $40 \mathrm{mM}$ ) with concomitant reduction of sulfate. Acetate was not degraded further after prolonged incubation. Thiosulfate was also utilized as an electron acceptor. Fe(III), sulfite, nitrate, nitrite and fumarate were not utilized.

\section{Chemotaxonomic characteristics}

The genomic DNA $\mathrm{G}+\mathrm{C}$ content of strain $\mathrm{PB}^{\mathrm{T}}$ was $53.5 \mathrm{~mol} \%$ as determined by HPLC. Quinone analysis revealed that strain $\mathrm{PB}^{\mathrm{T}}$ contained MK-7 as the major quinone component.

\section{Phylogenetic analysis}

Nearly the full length (1462 bp) of the 16S rDNA sequence of strain $\mathrm{PB}^{\mathrm{T}}$ was determined. The sequence was aligned and compared with 18 representative 


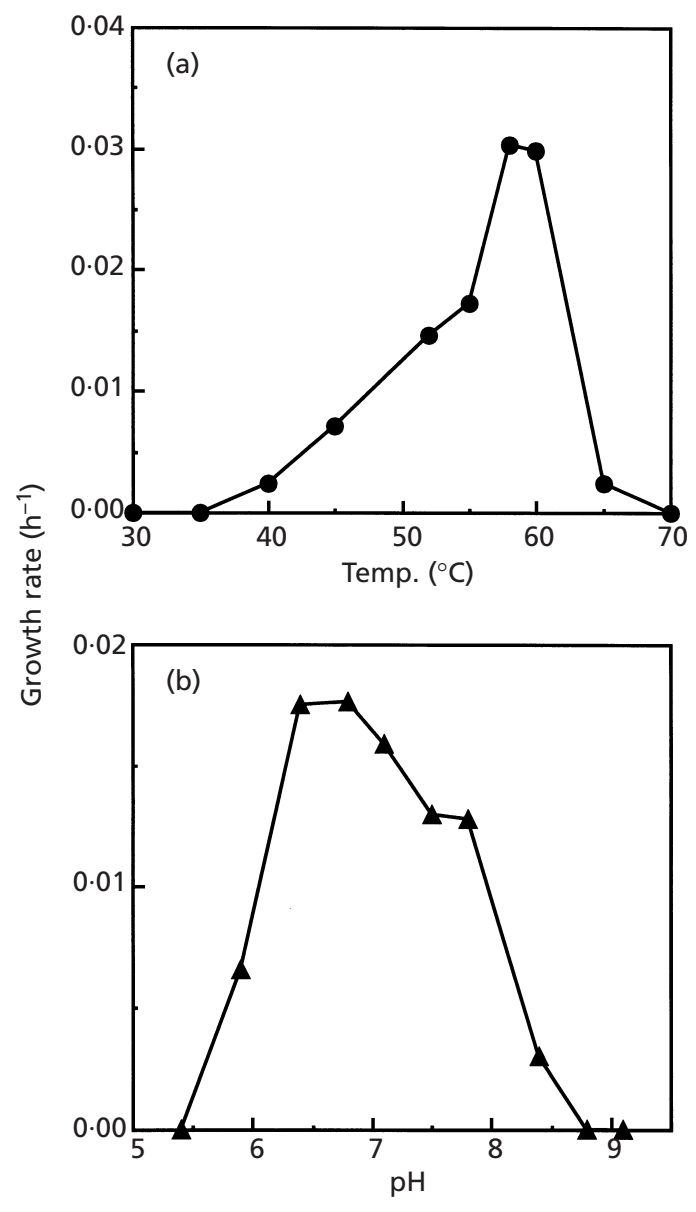

Fig. 4. Effect of temperature (a) and $\mathrm{pH}(\mathrm{b})$ on the growth of strain $\mathrm{PB}^{\mathrm{T}}$.

sequences of other bacteria. On the basis of the phylogenetic analysis (Fig. 5), strain $\mathrm{PB}^{\mathrm{T}}$ was found to be a member of the Bacillus-Clostridium subphylum of the Gram-positive bacteria, and the closest relative was Thermoterrabacterium ferrireducens $(87.4 \%$ similarity).

\section{DISCUSSION}

In this report, we have described a novel strictly anaerobic, thermophilic acetate-oxidizing syntroph. In pure culture, this strain grew acetogenically on several alcohols, organic acids, methoxylated aromatics and some amino acids. The strain could also grow autotrophically on hydrogen $/ \mathrm{CO}_{2}$ to produce acetate as the major product.

With regard to the other syntrophic acetate-oxidizing bacteria, two syntrophs have been previously isolated and characterized: a thermophilic syntroph, strain AOR (Lee \& Zinder, 1988), and a mesophilic syntroph, Clostridium ultunense (Schnürer et al., 1996). Table 1 shows the properties of these two isolates and our strain. All the isolates show acetogenic growth in pure culture.

One of the very interesting features that distinguish strain $\mathrm{PB}^{\mathrm{T}}$ from the other two strains was that the strain can oxidize acetate in pure culture by using sulfate as the electron acceptor. This trait is very similar to several sulfate-reducing bacteria belonging to the genus Desulfotomaculum. Desulfotomaculum acetoxidans and $D$. thermoacetoxidans are able to oxidize acetate completely with sulfate reduction (Widdel \& Pfennig, 1977; Min \& Zinder, 1990). Strain $\mathrm{PB}^{\mathrm{T}}$ is phylogenetically affiliated with the Grampositive low $\mathrm{G}+\mathrm{C}$ group, which also includes Desulfotomaculum species (Fig. 5). Moreover, strain $\mathrm{PB}^{\mathrm{T}}$, as well as Desulfotomaculum species, contains MK-7 as the major quinone component. These indicate that our isolate harbours a sulfate-respiration system. The other feature of such micro-organisms including our isolate is that they are also capable of growing acetogenically on pyruvate or methoxylated aromatics in the absence of sulfate (Min \& Zinder, 1990; Tasaki et al., 1992, 1993; Nilsen et al., 1996). Considering the fact that those Desulfotomaculum strains harbour the enzymes of the carbon monoxide dehydrogenase pathway that allows the microbes to convert methoxylated compounds to acetate, it is very likely that our isolate has a similar pathway.

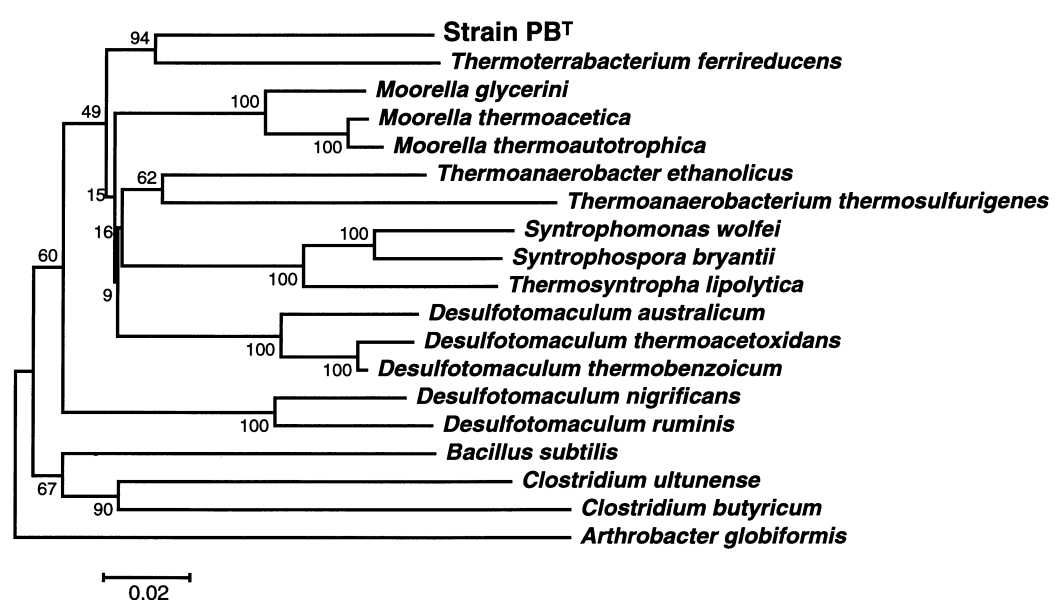

Fig. 5. Phylogenetic position of strain $\mathrm{PB}^{\top}$ within the Bacillus-Clostridium subphylum of the Gram-positive bacteria. The tree was based on 16S rDNA sequences and was constructed using the neighbour-joining method. Bar, 0.02 base substitutions per nucleotide position. 
Table 1. Characteristics of strain $\mathrm{PB}^{\top}$ and other syntrophic acetate-oxidizing bacteria

ND, Not determined.

\begin{tabular}{|c|c|c|c|}
\hline Characteristic & Strain $\mathbf{P B}^{\mathrm{T}} *$ & Strain $A O R \dagger$ & C. ultunense \\
\hline Cell size $(\mu \mathrm{m})$ & $0.4-0.7 \times 2-12 \cdot 6$ & $0 \cdot 4-0 \cdot 6 \times 2-3$ & $0 \cdot 5-0.7 \times 0.5-7$ \\
\hline Spore formation & + & - & + \\
\hline Gram stain & + & + & + \\
\hline Temperature range $\left({ }^{\circ} \mathrm{C}\right)$ & $40-65$ & $50-65$ & $15-50$ \\
\hline Optimum temperature $\left({ }^{\circ} \mathrm{C}\right)$ & 58 & 60 & 37 \\
\hline $\mathrm{pH}$ range & $5 \cdot 9-8 \cdot 4$ & ND & $5-10$ \\
\hline Optimum pH & $6 \cdot 8$ & ND & 7 \\
\hline DNA G $+\mathrm{C}$ content $(\mathrm{mol} \%)$ & $53 \cdot 5$ & 47 & 32 \\
\hline Major menaquinone & MK-7 & ND & ND \\
\hline Supplement required & None & Yeast extract & Yeast extract \\
\hline \multicolumn{4}{|l|}{ Utilization of substrate: } \\
\hline \multicolumn{4}{|l|}{ In pure culture } \\
\hline Hydrogen $/ \mathrm{CO}_{2}$ & + & + & - \\
\hline Formate & + & + & + \\
\hline Ethylene glycol & - & + & + \\
\hline Methanol & + & - & - \\
\hline Ethanol & + & - & - \\
\hline n-Propanol & + & - & ND \\
\hline n-Butanol & + & - & - \\
\hline 1,2-Propanediol & - & + & - \\
\hline 2,3-Butanediol & + & - & ND \\
\hline Ethanolamine & + & - & - \\
\hline Glycerol & - & - & - \\
\hline Pyruvate & + & + & + \\
\hline 3,4,5-Trimethoxybenzoate & + & - & - \\
\hline Syringate & + & ND & - \\
\hline Vanillate & + & ND & - \\
\hline Glycine & + & - & - \\
\hline Betaine & - & + & + \\
\hline Methylamine & - & - & - \\
\hline Cysteine & + & ND & + \\
\hline Glucose & - & - & + \\
\hline Acetate & - & - & - \\
\hline Acetate plus sulfate & + & - & - \\
\hline \multicolumn{4}{|l|}{ In co-culture with methanogen } \\
\hline Acetate & + & + & + \\
\hline
\end{tabular}

* This study.

$\dagger$ Data from Lee \& Zinder (1988).

† Data from Schnürer et al. (1996).

Phylogenetic analysis based on 16S rDNA sequence showed that strain $\mathrm{PB}^{\mathrm{T}}$ was most closely related to an iron-reducing, non-spore forming bacterium, Thermoterrabacterium ferrireducens (Slobodkin et al., 1997a) (Fig. 5). However, the sequence similarity was very low $(87 \cdot 4 \%)$. Moreover, strain PB $^{\mathrm{T}}$ differed from Thermoterrabacterium ferrireducens in several features: (1) strain $\mathrm{PB}^{\mathrm{T}}$ is not capable of utilizing $\mathrm{Fe}(\mathrm{III})$ as an electron acceptor; (2) it is a spore former; (3) it has a much higher DNA $\mathrm{G}+\mathrm{C}$ content. Our strain is rather related to the genus Moorella than to Thermo- terrabacterium in several features such as cell morphology, substrate utilization, physiological properties, quinone composition and the $\mathrm{G}+\mathrm{C}$ content of DNA (Fontaine et al., 1942; Wiegel et al., 1981; Hippe et al., 1992; Collins et al., 1994; Slobodkin et al., 1997b). However, Moorella spp. do not have the ability to reduce sulfate. These special features are clearly enough to distinguish our isolate from the other genera. On the basis of phenotypic and phylogenetic distinctiveness of the isolate, we concluded that the organism characterized here represents a novel and 
distinct taxon for which we propose the name Thermacetogenium phaeum gen. nov., sp. nov.

\section{Description of Thermacetogenium gen. nov.}

Thermacetogenium (therm.a.ce.to.ge'ni.um. Gr. adj. thermos warm; L. n. acetum vinegar; Gr. v. suff. genium producing; M.L. neut. n. Thermacetogenium thermophilic vinegar producer).

Cells are rod shaped. Strictly anaerobic and thermophilic. Chemoautotrophic and chemo-organotrophic. Gram reaction is negative, but shows a Gram-positive cell-wall structure. Round terminal endospores are formed. Colonies are disc shaped. Cells are able to oxidize acetate in co-culture with hydrogenotrophic micro-organisms. Acetate can be utilized also by sulfate reduction in pure culture. MK-7 is the major quinone. Grows acetogenically on several alcohols, methoxylated aromatics, organic acids, amino acids and hydrogen $/ \mathrm{CO}_{2}$. Sugars are not utilized. Additional supplements are not required.

\section{Description of Thermacetogenium phaeum sp. nov.}

Thermacetogenium phaeum (phae'um. Gr. adj. phaios brown, referring to the colour of the colonies; M.L. neut. adj. phaeum brown).

Cells are straight or slightly curved and rod shaped, $0 \cdot 4-0.7 \mu \mathrm{m}$ wide and $2 \cdot 0-12.6 \mu \mathrm{m}$ long. Occur singly, in pairs or in chains. Round terminal endospores are observed. Colonies are disc shaped, $1-3 \mathrm{~mm}$ in diameter, smooth and brownish. Methanol, ethanol, npropanol, n-butanol, 2,3-butanediol, ethanolamine, pyruvate, 3,4,5-trimethoxybenzoate, syringate, vanillate, glycine, cysteine, formate, and hydrogen $/ \mathrm{CO}_{2}$ are utilized in pure culture. Acetate is the primary fermentation product. Sugars are not utilized. Organic nutrients such as yeast extract are not required for growth. Acetate is oxidized to $\mathrm{CO}_{2}$ in co-culture with hydrogen-utilizing methanogens. Acetate is also oxidized to $\mathrm{CO}_{2}$ in pure culture with reduction of sulfate or thiosulfate as the electron acceptor. Sulfite, nitrate, nitrite, $\mathrm{Fe}(\mathrm{III})$ and fumarate are not utilized when acetate is used as the electron donor. Temperature range for growth is $40-65^{\circ} \mathrm{C}$, with an optimum at $58^{\circ} \mathrm{C}$. Growth is observed at a $\mathrm{pH}$ range from 5.9 to 8.4 , and the optimum is $\mathrm{pH} 6.8$. Growth occurs in the presence of $\mathrm{NaCl}$ at $0.05-4.5 \%(\mathrm{w} / \mathrm{v})$. The $\mathrm{G}+\mathrm{C}$ content of DNA is $53.5 \mathrm{~mol} \%$. The major quinone is MK-7. The type strain is Thermacetogenium phaeum strain $\mathrm{PB}^{\mathrm{T}}$ ( = DSM 12270 $)$.

\section{ACKNOWLEDGEMENTS}

We thank Xian-Ying Meng at National Institute of Bioscience and Human Technology (NIBH) Agency of Industrial Science and Technology for taking the electron micrographs. We also thank Yasuyo Ashizawa at NIBH for her help with the quinone analysis and Yoko Ueda at NIBH for her assistance with the determination of DNA $\mathrm{G}+\mathrm{C}$ content. We thank Yuji Sekiguchi at Nagaoka University of Technology for his critical reading of the manuscript.

\section{REFERENCES}

Barker, H. A. (1936). On the biochemistry of methane fermentation. Arch Microbiol 7, 404-419.

Collins, M. D., Lawson, P. A., Willems, A., Cordoba, J. J., Fernandez-Garayzabal, J., Garcia, P., Cai, J., Hippe, H. \& Farrow, J. A. E. (1994). The phylogeny of the genus Clostridium: proposal of five new genera and eleven new species combinations. Int $J$ Syst Bacteriol 44, 812-826.

DSMZ (1993). Catalogue of strains, 5th edn. Braunschweig: Gesellschaft für Biotechnologische Forschung.

Ferry, J. G. (1992). Methane from acetate. J Bacteriol 174, 5489-5495.

Fontaine, F. E., Peterson, W. H., McCoy, E., Johnson, M. J. \& Ritter, G. J. (1942). A new type of glucose fermentation by Clostridium thermoaceticum n. sp. J Bacteriol 43, 701-715.

Hippe, H., Andreesen, J. R. \& Gottschalk, G. (1992). The genus Clostridium-nonmedical. In The Prokaryotes, p. 1800-1866. Edited by A. Balows, H. G. Trüper, M. Dworkin, W. Harder \& K.-H. Schleifer. New York: Springer.

Hiraishi, A. (1992). Direct automated sequencing of 16S rDNA amplified by polymerase chain reaction from bacterial cultures without DNA purification. Lett Appl Microbiol 15, 210-213.

Kamagata, Y. \& Mikami, E. (1989). Diversity of acetotrophic methanogens in anaerobic digestion. In Recent Advances in Microbial Ecology, pp. 459-464. Edited by T. Hattori, Y. Ishida, Y. Maruyama, R. Y. Morita \& A. Uchida. Tokyo: Japan Scientific Society.

Kamagata, Y. \& Mikami, E. (1991). Isolation and characterization of a novel thermophilic Methanosaeta strain. Int J Syst Bacteriol 41, 191-196.

Lee, M. J. \& Zinder, S. H. (1988). Isolation and characterization of a thermophilic bacterium which oxidizes acetate in syntrophic association with a methanogen and which grows acetogenically on $\mathrm{H}_{2} / \mathrm{CO}_{2}$. Appl Environ Microbiol 54, 124-129.

Lovley, D. R. \& Klug, M. J. (1982). Intermediary metabolism of organic matter in the sediments of a eutrophic lake. Appl Environ Microbiol 43, 552-560.

Mackie, R. I. \& Bryant, M. P. (1981). Metabolic activity of fatty acid-oxidizing bacteria and the contribution of acetate, propionate, butyrate, and $\mathrm{CO}_{2}$ to methanogenesis in cattle waste at 40 and $60^{\circ} \mathrm{C}$. Appl Environ Microbiol 41, 1363-1373.

Min, H. \& Zinder, S. H. (1990). Isolation and characterization of a thermophilic sulfate-reducing bacterium Desulfotomaculum thermoacetoxidans sp. nov. Arch Microbiol 153, 399-404.

Mountfort, D. O. \& Asher, R. A. (1978). Changes in proportions of acetate and carbon dioxide used as methane precursors during the anaerobic digestion of bovine waste. Appl Environ Microbiol 35, 648-654.

Nilsen, R. K., Torsvik, T. \& Lien, T. (1996). Desulfotomaculum thermocisternum sp. nov., a sulfate reducer isolated from a hot north sea oil reservoir. Int J Syst Bacteriol 46, 397-402.

Petersen, S. P. \& Ahring, B. K. (1991). Acetate oxidation in a thermophilic anaerobic sewage-sludge digester: the importance of non-aceticlastic methanogenesis from acetate. FEMS Microbiol Ecol 86, 149-158.

Saito, N. \& Nei, M. (1987). The neighbor-joining method: a new method for constructing phylogenetic trees. Mol Biol Evol 4, 406-425. 
Schink, B. (1997). Energetics of syntrophic cooperation in methanogenic degradation. Microbiol Mol Biol Rev 61, 262-280.

Schnürer, A., Houwen, F. P. \& Svensson, B. H. (1994). Mesophilic syntrophic acetate oxidation during methane formation by a triculture at high ammonium concentration. Arch Microbiol 162, 70-74.

Schnürer, A., Schink, B. \& Svensson, B. H. (1996). Clostridium ultunense sp. nov., a mesophilic bacterium oxidizing acetate in syntrophic association with a hydrogenotrophic methanogenic bacterium. Int J Syst Bacteriol 46, 1145-1152.

Slobodkin, A., Reysenbach, A. L., Strutz, N., Dreier, M. \& Wiegel, J. (1997a). Thermoterrabacterium ferrireducens gen. nov., sp. nov., a thermophilic anaerobic dissimilatory Fe(III)-reducing bacterium from a continental hot spring. Int J Syst Bacteriol 47, 541-547.

Slobodkin, A., Reysenbach, A. L., Mayer, F. \& Wiegel, J. (1997b). Isolation and characterization of the homoacetogenic thermophilic bacterium Moorella glycerini sp. nov. Int J Syst Bacteriol 47, 969-974.

Stams, A. J. M. (1994). Metabolic interactions between anaerobic bacteria in methanogenic environments. Antonie Leeuwenhoek 66, 271-294.

Tamaoka, J. \& Komagata, K. (1984). Determination of DNA base composition by reversed-phase high-performance liquid chromatography. FEMS Microbiol Lett 25, 125-128.

Tamaoka, J., Katayama-Fujimura, Y. \& Kuraishi, H. (1983). Analysis of bacterial menaquinone mixtures by high performance liquid chromatography. $J$ Appl Bacteriol 54, 31-36.
Tasaki, M., Kamagata, Y., Nakamura, K. \& Mikami, E. (1992). Utilization of methoxylated benzoates and formation of intermediates by Desulfotomaculum thermobenzoicum in the presence or absence of sulfate. Arch Microbiol 157, 209-212.

Tasaki, M., Kamagata, Y., Nakamura, K., Okamura, K. \& Minami, K. (1993). Acetogenesis from pyruvate by Desulfotomaculum thermobenzoicum and differences in pyruvate metabolism among three sulfate-reducing bacteria in the absence of sulfate. FEMS Microbiol Lett 106, 259-264.

Thompson, J. D., Higgins, D. G. \& Gibson, T. J. (1994). CLUSTAL $\mathrm{W}$ : improving the sensitivity of progressive multiple sequence alignment through sequence weighting, position-specific gap penalties and weight matrix choice. Nucleic Acids Res 22, 4673-4680.

Uemura, S. \& Harada, H. (1993). Microbial characteristics of methanogenic sludge consortia developed in thermophilic UASB reactors. Appl Microbiol Biotechnol 39, 654-660.

Weisburg, W. G., Barns, S. M., Pelletier, D. A. \& Lane, D. J. (1991). $16 \mathrm{~S}$ ribosomal DNA amplification for phylogenetic study. $J$ Bacteriol 173, 697-703.

Widdel, F. \& Pfennig, N. (1977). A new anaerobic, sporing, acetate-oxidizing, sulfate-reducing bacterium, Desulfotomaculum (emend.) acetoxidans. Arch Microbiol 112, 119-122.

Wiegel, J., Braun, M. \& Gottschalk, G. (1981). Clostridium thermoautotrophicum species novum, a thermophile producing acetate from molecular hydrogen and carbon dioxide. Curr Microbiol 5, 255-260.

Zinder, S. H. \& Koch, M. (1984). Non-aceticlastic methanogenesis from acetate: acetate oxidation by a thermophilic syntrophic coculture. Arch Microbiol 138, 263-272. 